International Journal of Social Science And Human Research

ISSN(print): 2644-0679, ISSN(online): 2644-0695

Volume 04 Issue 12 December 2021

DOI: $10.47191 / \mathrm{ijsshr} / \mathrm{v} 4-\mathrm{i} 12-20$, Impact factor-5.586

Page No: 3606-3609

\title{
The Effect of Training with Blended Project-based Learning on The Lecturer's Competence in Developing Teaching Materials
}

\author{
Fajar Arianto $^{1}$, Sulistiowati ${ }^{2}$, Mustaji ${ }^{3}$, Andi Kristanto ${ }^{4}$, Andi Mariono ${ }^{5}$ \\ 1,2,3,4,5 Teknologi Pendidikan, Universitas Negeri Surabaya, Indonesia
}

\begin{abstract}
This research objective was to determine the effect of training with blended project-based learning on the lecturers' competence in developing teaching materials. The research participants consisted of 15 lecturers. The research method was a weak experimental by comparing the results of the participants' pretest and posttest. The data analysis technique of this research used N-gain of the pretest and posttest. The results showed that the N-gain score of $63.61 \%$ was classified as medium. Training with blended project-based learning for lecturers had a significant effect in increasing the competence of developing teaching materials. Blended project-based learning could increase the participation and the trainees' positive attitude.
\end{abstract}

KEYWORDS: Blended, project-based learning, training, competency, instructional material

\section{INTRODUCTION}

Lecturers' competence is one of the factors that cause unemployment among graduates (Hanapi \& Nordin, 2014 ). In the era of the industrial revolution 4.0, the challenges of college graduates are getting bigger, and they must have superior competencies to compete globally (Bendriyanti, Dewi, \& Julita, 2019 ). The development in human resources followed by the quality of learning improvement is one way to fulfil higher education performance targets. Lecturers are encouraged to carry out problem-based, collaborative learning and not rely on learning in the classroom. One of the ways to realize it is that lecturers should have teaching materials following the established curriculum. The development of teaching materials is one indicator of lecturers' performance in supporting the leading performance indicators of higher education. Teaching materials in the leading performance indicators can be used as recognition for people utilize.

During the pandemic in 2020-2021, the improvement of lecturers' competence was continuously carried out, namely by using blended project-based learning. Blended project-based learning is a combination of face-to-face and online training that produces a product. Blended learning in this training combines face-to-face meetings with online learning (Oliver \& Trigwell, 2005), instructor-coordinated training, and asynchronous self-study in the workplace (Singh, 2021). Project-based learning is learning related to projects that develop learners' knowledge and skills (Chanpet, Chomsuwan, \& Murphy, 2020). Blumenfeld (1991) states that project-based learning canters on the use of long-term investigations that emphasize deepening understanding, solutions that encourage the regulation of learning needs, and produce project artifacts as the comprehension result (Land \& Zembal-Saul, 2003). The essence of project-based learning is the acquisition of materials, knowledge, and skills from a production process through ways that are preferred by learners (Lee \& Tsai, 2004). Project-based learning is advantageous for students. They can develop their skills in gathering and presenting data, developing thinking skills, increasing motivation based on an individual's learning style, and developing independent learning abilities (Orevi and Danon, 1999 in Frank, Lavy, et al. \& Elata, 2003).

Blended project-based learning allows learners to practice using various skills required for their careers through face-to-face training, synchronous online, and asynchronous self-study. Huy, Luong, \& Vu (2020) show that badminton training participants showed excellent perceptions of blended learning. A combination of blended learning with project-based learning in Yustina, Syafii, \& Vebrianto's research (2020) showed teachers' creative thinking increase. Blended learning in teacher training had a positive effect, and trained teachers preferred blended learning (Le \& Pham, 2021). The application of Blended learning was reasonably practical and obtained better results than traditional face-to-face or online learning, and participants became more independent and autonomous in their learning (Namyssova, et al., 2019).

\section{METHODS}

This research used the weak experimental method because it used one group of participants with a one-group pretest-posttest design. The research procedure consisted of some steps, including the participants performing the teaching material products 

Materials

developed before the treatment and showing the products produced from participating in the training of blended project-based learning after the treatment. The research products were teaching materials for lectures with criteria for conformity to learning objectives, student-centered criteria, learning-centered criteria, context-centered criteria, and presentation (Dick, Carey, \& Carey, 2015). The research participants amounted to 15 lecturers. The data analysis technique of this research compared the product results before and after training using $\mathrm{N}$-gain. Hake (1999) determined the criteria for the $\mathrm{N}$-gain score, namely $(<\mathrm{g}\rangle)<0.3$ including 'low-g'; $0.7>(\langle\mathrm{g}\rangle)>0.3$ is classified as 'medium-g'; $(\langle\mathrm{g}\rangle)>0.7$ is classified as 'high-g'.

\section{RESULT AND DISCUSSION}

The research results were analyzed by $\mathrm{N}$-gain (table 1). The results showed an $\mathrm{N}$-gain score of $63.61 \%$. It can be concluded that training using blended learning was entirely (medium) effective based on the scale of Hake (1999). The training participants experienced an increase in the ability to develop teaching materials for lectures, from an average of 41.33 at the pretest to an increase of 73.8 (posttest).

Table 1. Calculation of $\mathbf{N}$-gain for the development of teaching materials

\begin{tabular}{|l|l|l|l|l|l|l|}
\hline No. & Pretest & posttest & $\begin{array}{l}\text { Posttest- } \\
\text { Pretest }\end{array}$ & $\begin{array}{l}\text { Ideal Score } \\
(\mathbf{8 4})\end{array}$ & $\begin{array}{l}\text { N-gain } \\
\text { score }\end{array}$ & $\begin{array}{l}\text { N-gain } \\
\text { score (\%) }\end{array}$ \\
\hline 1 & 43 & 72 & 29 & 55 & 0,53 & 52,73 \\
\hline 2 & 38 & 73 & 35 & 49 & 0,71 & 71,43 \\
\hline 3 & 40 & 73 & 33 & 51 & 0,65 & 64,71 \\
\hline 4 & 41 & 73 & 32 & 52 & 0,62 & 61,54 \\
\hline 5 & 47 & 74 & 27 & 57 & 0,47 & 47,37 \\
\hline 6 & 41 & 74 & 33 & 51 & 0,65 & 64,71 \\
\hline 7 & 40 & 72 & 32 & 52 & 0,62 & 61,54 \\
\hline 8 & 42 & 76 & 34 & 50 & 0,68 & 68,00 \\
\hline 9 & 46 & 75 & 29 & 55 & 0,53 & 52,73 \\
\hline 10 & 43 & 74 & 31 & 53 & 0,58 & 58,49 \\
\hline 11 & 36 & 71 & 35 & 49 & 0,71 & 71,43 \\
\hline 12 & 43 & 72 & 29 & 55 & 0,53 & 52,73 \\
\hline 13 & 41 & 73 & 32 & 52 & 0,62 & 61,54 \\
\hline 14 & 39 & 77 & 38 & 46 & 0,83 & 82,61 \\
\hline 15 & 40 & 78 & 38 & 46 & 0,83 & 82,61 \\
\hline Sum & 620 & 1107 & 487 & 773 & 9,54 & 954,14 \\
\hline Average & $\mathbf{4 1 , 3 3}$ & $\mathbf{7 3 , 8}$ & 32,47 & 51,53 & $\mathbf{0 , 6 4}$ & $\mathbf{6 3 , 6 1}$ \\
\hline
\end{tabular}

The use of blended project-based learning in this research increased the quality of teaching materials developed by lecturers as training participants. Blended learning could increase participants' attendance and increase retention (Bowyer \& Chambers, 2017). In developing teaching materials, participants used e-learning to support blended project-based learning. Therefore, they could discuss with tutors and colleagues. Project-based learning carried out by trainees has developed responsibility and confidence in completing projects (Doppelt, 2003). Combining blended with project-based learning made participants have a positive learning attitude and were active in discussions that made them confident (Hsieh, Lou, \& Shih, 2013).

The devices used in blended learning significantly affected the ease of accessing learning materials, providing feedback, and communication that impacted learning independence and participant activity (Stepanova, 2020). Trainees with blended learning had more time to learn and allowed participants to reflect on their learning outcomes (Senkoylu, Senkoylu, \& Budakoglu, 2020). The utilization of information technology in project-based learning increased activity and interaction between participants and instructors (Chanpet, Chomsuwan, \& Murphy, 2020). Combining blended project-based learning with e-learning provided participants with informative guidance strategies and quick feedback to directly and quickly utilize the available teaching materials (Hou, Chang, \& Sung, 2007).

Blended project-based learning supported participants to work collaboratively by utilizing e-learning support and rapid feedback from instructors (Lou \& MacGregor, 2004). Instructors in facilitating online involved various things, including creating an environment, managing learning processes and assignments, managing content, guiding processes, and creating community (Holt, Kleiber, Swenson, Rees, \& Milton, 1998). The utilization of e-learning in blended learning increased participant participation in training and made the training process more effective (Hameed, Badii, \& Cullen, 2008). 


\section{The Effect of Training with Blended Project-based Learning on The Lecturer's Competence in Developing Teaching Materials}

\section{CONCLUSION}

The training to increase the competence of lecturers using blended project-based learning was reasonably practical. Blended project-based learning could activate training participants, both face-to-face and online. The provision of support in e-learning in blended learning helped participants learn and deepen the material presented. Training participants could communicate directly with colleagues and training instructors using e-learning facilities. Providing direct feedback to training participants through elearning in blended learning has increased the participation and independence of trainees.

\section{REFERENCES}

1) Bendriyanti, R. P., Dewi, C., \& Julita, R. (2019 ). Lecturer and Literacy In Higher Education. Journal of critical reviews, 48-51.

2) Bowyer, J., \& Chambers, L. (2017). Evaluating blended learning: Bringing the elements together. Research Matters, 1726.

3) Chanpet, P., Chomsuwan, K., \& Murphy, E. (2020). Online Project-Based Learning and Formative Assessment. Technology, Knowledge and Learning, 685-705 .

4) Dick, W., Carey, L., \& Carey, J. O. (2015). The Systematic Design of Instruction. New York: Pearson.

5) Dikti, D. (2020). Buku Panduan Indikator Kinerja Utama (IKU) Perguruan Tinggi. Jakarta: Ditjen Dikti.

6) Doppelt, Y. (2003). Implementation and Assessment of Project-Based Learning in a Flexible Environment. International Journal of Technology and Design Education, 255-272.

7) Frank, M., Lavy, I., \& Elata, D. (2003). Implementing the Project-Based Learning Approach in an Academic Engineering Course. International Journal of Technology and Design Education, 273-288.

8) Hake, R. R. (1999). Analayze Change/Gain Score. Woodland Hills: Indiana University.

9) Hameed, S., Badii, A., \& Cullen, A. J. (2008). Effective E-Learning Integration with Traditional Learning in a Blended Learning Environment . European and Mediterranean Conference on Information Systems (pp. 1-16). Dubai : European and Mediterranean Conference on Information Systems .

10) Hanapi, Z., \& Nordin, M. S. ( 2014 ). Unemployment among Malaysia Graduates:Graduates'attributes,Lecturers' Competency and Quality Of Education. International Conference on Education \& Educational Psychology 2013 (pp. 1056 - 1063 ). Antalya: Elsevier Ltd.

11) Holt, M. E., Kleiber, P. B., Swenson, J. D., Rees, E. F., \& Milton, J. (1998). Facilitating Group Learning on the Internet. New Directions for Adult and Continuing Education, 43-51.

12) Hou, H.-T., Chang, K.-E., \& Sung, Y.-T. (2007). An Analysis of Peer Assessment Online Discussions within a Course that uses Project-based Learning. Interactive Learning Environments, 237-25.

13) Hsieh, H.-Y., Lou, S.-J., \& Shih, R.-C. (2013). Applying Blended Learning with Creative Project-Based Learning: A Case Study of Wrapping Design Course for Vocational High School Students . The Online Journal of Science and Technology-, 18-27.

14) Huy, C. V., Luong, N. T., \& Vu, N. N. (2020). Blended Learning in Badminton Training for Professionals: Students'perceptions and Performance Impacts. European Journal of Physical Education and Sport Science, 28-36.

15) Land, S. M., \& Zembal-Saul, C. (2003). Scaffolding reflection and articulation of scientific explanations in a data-rich, project-based learning environment: An investigation of progress portfolio. Educational Technology Research and Development, 65-84.

16) Le, P. T., \& Pham, H. T. (2021). Using Blended Learning in Teacher Training Programs: Perspectives of Pre-service Teachers. Journal of Educational and Social Research, 115-127.

17) Lee, C.-I., \& Tsai, F.-Y. (2004). Internet project-based learning environment: the effects of thinking styles on learning transfer. Journal of Computer Assisted Learning, 31-39.

18) Lou, Y., \& MacGregor, S. K. (2004). Enhancing project-based learning through online between-group collaboration. Educational Research and Evaluation, 419-140.

19) Namyssova, G., Tussupbekova, G., Helmer, J., Malone, K., Afzal, M., \& Jonbekova, D. (2019). Challenges and benefits of blended learning in higher education. International Journal of Technology in Education, 22-31.

20) Oliver, M., \& Trigwell, K. (2005). Can 'Blended Learning' Be Redeemed? E-Learning, 17-26.

21) Senkoylu, A., Senkoylu, B., \& Budakoglu, I. (2020). Blended Learning Is a Feasible and Effective Tool for Basic Pediatric Spinal Deformity Training . Global Spine Journal, 219-223.

22) Singh, H. (2021). Building Effective Blended Learning Programs. In B. H. Khan, S. A., S. H. Salha, \& Z. N. Khlaif, Challenges and Opportunities for the Global Implementation of E-Learning Frameworks (pp. 51-54). Hersey: IGI Global. 
The Effect of Training with Blended Project-based Learning on The Lecturer's Competence in Developing Teaching Materials

23) Stepanova, E. V. (2020). The blended learning in higher education. The European Proceedings of Social and Behavioural Sciences , 871-880.

24) Yustina, Syafii, W., \& Vebrianto, R. (2020). The Effects of Blended Learning and Project-Based Learning on PreService Biology Teachers' Creative Thinking Through Online Learning. Jurnal Pendidikan IPA Indonesia, 408-420. 